\title{
Importance of Scientific Management in the Modern Management
}

\author{
Savel Kamal \\ Tishk International University, Sulaymaniyah Campus, Iraq \\ Business and Management Department \\ savel.kamal@std.tiu.edu.iq
}

DOI: 10.47299/bsjmm.v1i2.60

\begin{abstract}
Management has a vital importance in every step of our life. Further, executing the required tasks in the organizations in the best manner should have significant contributions to the business' effectiveness. Therefore, this paper attempts to explain the history of management briefly and discusses how classical management has impacted modern management. In specific, the purpose is to understand the contributions of Frederic Taylor to the management science.
\end{abstract}

Keywords: Scientific management, rule of thumb, hierarchy, employee morals, risk management, diversification, traditional management

\section{Introduction}

The term "management" is often used interchangeably with "administration" in the business world. Administration can be defined as a collaborative set of principles that often deal with the behaviors of managing a group or groups of people and data. Administration processes exist in all organizations, regardless of the nature, purpose, and philosophy of the business. Megginson, Mosley, and Pietri (2001) have previously explained the term administration as functioning with people, economical and physical sources to accomplish organizational aims by operating "planning, organizing, leading and controlling functions." Kreitner (1982) defined administration as a procedure to solve issues that have an impact to accomplish organizational goals.

Administration helps organize, shape, and solve the issues in any organization (Budur, 2018b). It is also a tool to get things done to accomplish a goal through a person or a group of people (Demir \& Budur, 2019; Durmaz, 2017). There has always been a debate whether administration should be considered as an art or science. It is usually believed that those with strong academic background are better administrators as most of the CEOs of successful companies are university graduates with impeccable educational records.

John F. Kennedy, one of the former presidents of the USA, described administration as a role played in the community for the purpose of aiding people advance in their life. He believed that the five primary tasks of an administrator include planning for the future, organizing important content, staffing the right people, direction people in the correct direction and controlling their contributions (Management Study, 2020).

Management has changed over the years, and there is a clear distinction between the old or classical and modern management practices (Budur \& Demir, 2019a). Like most developing nations of the 
world, Kurdistan Region of Iraq has also been struggling to strike a perfect balance between the modern and classical management styles. All businesses in the part were operated by locals and there were no international or multinational companies in this region (Budur \& Poturak, 2020). However, in the past two decades, the region is attracting a lot of attention by the foreign investors and many famous international and multinational companies such as Carrefour, Lafarge, LC Waikiki started operating here, thus bringing their own culture and management styles to the region (Budur \& Poturak, 2021). Big companies like Asia Cell, Korek telecom, and Qaiwan group are locally owned, but they have brought diverse foreign managers to improve the quality of management in their companies (Budur, 2018a). It is very important for all the managers to know the history of management, its evolution and to understand the difference between modern and classical management styles. Only then they will be able to choose the management philosophy that fits their organization perfectly.

\section{Literature Review}

While administration concepts were in practice for centuries years without the term being identified as what we know of it as of today, it was Fredrick Taylor who branded it as a science. While he was praised for his legacy and vast contributions to the "science of management", he was also brutally criticized for his findings. The way he dealt with the people was criticized due to the reality that he considered people reason as part of knowledge. A lot of his commitments and findings are applicable today and his findings are continuously used in a variety of fields. Because of the reliability of his findings, it can be said that the judgment is often neglected and the main point of focus is on his achievements in the usage of scientific methods in administration. This came from his knowledge in his prior science works. It can be said that the different methods for employing people was through basic interviews and an evaluation and analysis on whether the person was right for the job. After answering that question, the person was either employed or not. With Taylor's findings, it was a lot more than just a simple question and answer.

Drucker (2019) elaborated on the significance of administration principles and appreciated production innovation as it could help reduce the poverty levels of the lower-class. Harold Koontz was also defined "management" as an art of a) getting things done with the help of individuals working in properly arranged teams, b) creating an environment in which individuals can and work together towards accomplishment of the team's goals. Fredrick W. Taylor had his own definition of "scientific management". He believed that administration was more than what people described it to be. According to Taylor, management is an art of knowing the right things as well knowing the right time of doing the right things (Taylor, 1911).

\section{Management's History}

Even though, the concept and applications of administration had existed in all walks of lifelong before administration or management itself was introduced and studied as a separate field about a century ago. The principles of management were applied to manage work and people in different fields. However, it was only after F. Taylor theories and principles of management were developed and people started to take management seriously. It was finally seen as a separate and significant area of business study (Savino, 2016). 
It is a general misconception that World War II was the time when the concept of "scientific management" was conceived. F. Taylor was in fact, the first person to introduce the term of "scientific management" in early 1900s. Several management strategies and tactics were used during both the world wars, and engineers, mathematicians and statisticians contributed substantially to the field of management (Ferraro, 2016). The administration strategies that were used during the World War I and II were identified and refined post World War II.

Later, technology played a vital role in the field of administration sciences. The algorithms and computational forms used in computer sciences related fields and technologies were used to develop management science. The methods used in computer sciences are used to solve very complicated issues that we face in our lives (Advameg, 2020).

\section{The Importance of Application of Management or Administration Theories}

The theories of management or administration, if applied effectively, help organizations and companies to have a clear focus, a good connection with the employees and achieve desired goals (Budur et al., 2018; Mohammed et al., 2020). They also facilitate an immaculate coordination between members and employees working for the organization. An effective application of relevant management theories not only saves time but also prevents any chaos in the work field (Budur \& Demir, 2019). When the employees and the management know how to do the right things and the right time of doing things, then meeting organizational goals become an achievable task (Zaim et al., 2020).

Nevertheless, this must be noted that the management theories, though widely used by organization all around the globe, are not the hard and fast rules or the universal laws (Faeq, 2020). The same theory that transforms an organization entirely, may fail when applied to another organizational setting (Kamal \& Shawkat, 2020). What may work for an area of business, may not necessarily work in other fields (Top et al., 2020). It is true that it is widely used, but it is not always used fully in every sector. When a set of theories are not applied effectively, new theories are proposed and developed by the academicians and practitioners. Therefore, new theory formulation in the field of management is a continuous phenomenon and is on the rise (Khan \& Yildiz, 2020).

\section{Who is Frederick Taylor?}

Fredrick W. Taylor was an American engineer and an inventor of management principles. Taylor is known as the father and founder of scientific management and its principles. His findings helped many advancements in different industries (Mee,2020). To get a better understanding of Taylor's work, it is important to understand his background. His father was a lawyer and Taylor himself entered New Hampshire's Philips Exeter Academy in 1872 as a class leader. Taylor also managed to pass his Harvard entrance exams but ended up abandoning the opportunity due to his eyesight problems that had risen because of his night studies (Mee, 2020). Three years later, Taylor joined Midvale Steel Company where he began working as a machine store laborer. He worked as the store assistant, machinist, head of drawing office and as an engineer's chief in his career at the company (Mee, 2020). At the age of 45 , Taylor retired from his machinist job, but spent a lot of his time as well as money to work and thus promote the principles of scientific management. His first approach was through lecturing at the 
universities and other professional societies. Acknowledging his great contributions to the engineering fields, in 1906, the society of mechanical engineers elected him as the president. In that same year, Taylor was also been awarded the honorary doctorate in the field of science by the University of Pennsylvania (Mee, 2020).

Many of Taylor's publishing articles were published in the society of mechanical engineers. These publications were "Notes on Belting" published in 1894, "A Piece Rate System" published in 1895, 'Shop Management' published in 1903, and 'On the Art of Cutting Metals' published in 1906. The Principles of Scientific Management, Taylor's most well-known study, was published in 1911 (Mee, 2020).

\section{Management before Fredrick Taylor}

Management before Taylor was a subjective matter of carrying out routine work without having to think of an organized way of doing it. Everyone simply would do things the way they believed was the correct way of doing them. The philosophy of management might have existed but there were no organized methods of getting things done until Taylor (Locke, 1982).

The effective and revolutionary methods of scientific management were introduced by Taylor when he implemented standard and basic rehearsal prior to starting the work to better the overall activities in the work field. The main reason why Taylor's methods are referred to as scientific management is due to his background knowledge and skills in science. He borrowed techniques from chemists, physicists, biologists and many more. He used scientific research and methods to create efficient workforce. He is often credited for leading the businesses to professionalism and efficiency (Taneja et al., 2011).

Before Frederick, management was only seen as an art but with his scientific techniques, today it is more of science than just art. Before Taylor, decisions were based on the rule of thumb, rather than using precise principles and procedures backed by evidence. Taylor's scientific management principles are based on the command-and-control theories due to his experience in the engineering field where he was taught to use close supervision while working (Kidwell \& Scherer, 2001).

\section{What is Frederick Taylor's theory?}

The summary of Taylor's principles are as follows: (Kidwell \& Scherer, 2001; Taneja et al., 2011):

Instead of using the traditional Rule of Thumb, the scientific method used in engineering should be applied to accomplish tasks.

Instead of randomly assigning people to jobs, match the people with the jobs, based on how well they suit the position in terms of their capacities and inspirations for the position.

Prior to the work, give suitable directions and supervision; also monitor the employee's performance closely so they work efficiently. 
Divide the tasks and work amid the managers and employees so that the employees can get their jobs done expeditiously.

\section{Frederick and Scientific Management Today}

When Taylor published "Scientific Management" in 1911, the implications were revolutionary as the organizations started to abandon the "Rule of Thumb" that had previously been used, and shifted towards the more logical system of scientific management (Locke, 1982). According to Taylor, every task needs a particular as well as a practical guidance to ensure that the person who has been given the task is indeed able to perform the task correctly. These tasks must be accomplished in a systematic way, rather than by following the rule of thumb. Several systems including the routing system, mnemonic system and a modernized costing scheme were developed after Taylor pointed out the need of standardizing the way of doing the tasks. Taylor referred to his standards are as "administration and its mechanisms" which were all extensions of the four principles stated above (Taneja et al., 2011).

When Taylor published his standards, he proposed the implications for all the organizations operating worldwide. He was confident that even the organizations on the verge of extinction due to their wrong management approach could use his principles to steer out of trouble. He also believed that his principles would maximize the work efficiency, and everything would be done the right way, by the right person, at the right time, and in an organized manner. The executions of his methods and standards indeed changed and increase the workers' productivity even in the struggling organizations (Nelson, 1974).

The major problem in the field of management was that people had a very limited knowledge of management. The managers or supervisors were not trained to supervise their workers properly, which resulted in poor work outcomes and thus the goals of productivity could not be achieved. Taylor's "choose the right person for the right place" principle helped solve the above-mentioned problem for the organization (Rahman, 2012). Another issue was that the operators were welleducated to achieve and function well with maximum efficiency, but the workers in general were not. Therefore, Taylor emphasized the importance of education the most, and made them work in a group more efficiently by sharing knowledge with others, instead of working individually (Metzgar, 2004). Taylor added several new duties to engineers' job description, such as:

To develop proper scientific methods to do the job.

Provide and create goals to the workers to increase productivity.

Provide and create a plan to achieve those goals.

Train the people to use these methods and achieve the goals.

This process was a constantly evolving one that included going from the "Rule of Thumb" to learning how to hire and train people and choosing them for the right position, instead of just randomly placing the wrong people at the wrong positions. It also helped managers and employees focus on identifying 
and dealing with the main problems instead of sweeping them under the carpet. Although this was a gradual process, but the more people read about Taylor's principles the more it proved to be effective, and the companies that adopted his management principles grew bigger and more successful than ever before (Boddewyn, 1961).

\section{Comparison of Classical and New Management in Organizations}

There is a huge difference between the classical and the new management theories and practices. Old administration practices made the organizations have a tall hierarchy. The flow of the orders and information in such organizations, was only vertically downwards. Hence, the operators had no say in decision making and they would only do what they were told to do, with no right of expressing opinions and suggesting ideas. In other words, the organizations mostly had a military like system that was hierarchical, organized and too disciplined to give any freedom of expression. All the worker in an organization were supposed to follow a strict set of guidelines that were set prior to starting the work (Rahman, 2012).

On the other hand, the organizations following the modern management philosophies have no restrictions on expressing opinions and ideas. The workers and operators have more freedom and flexibility at work (Rahman, 2012). Direct managers and upper management lend an ear to the lower ones to hear their thoughts and concerns regarding the organizational matters. Openness and flexibility help organization become adaptable to the rapidly changing business environment and come up with new inventions. Their goal is to promote diversity in their organization by hiring people with different background for different departments. They work collaboratively using diverse skills to achieve organizational goals (Poturak et al., 2020)

\section{The Main Points of Disagreement}

Stability: It is believed that the organizational culture, structure, and strategies of the businesses that follow the older management theories, are relatively stable due to lack of modification in the old management styles. On the other hand, the organizations following the modern management style, are instable and changing rapidly (Zardasht et al., 2020).

Flexibility: Classical organizations were rigid, whereas the modern organizations are very flexible since the employees are trained to expect the unexpected and behave accordingly when they encounter such a situation (Budur et al., 2019; Demir et al.,2019; Poturak et al., 2020).

Hierarchy: Classical organizations have a tall hierarchy whereas new organizations have a flat hierarchy.

Teamwork: In old organizations, there is not much of a teamwork and this is because of the commandand-control rule mentioned previously. New organizations focus more on working effectively in groups. Teamwork is the bedrock of modern organizations (Demir et al., 2020).

Employee Morale: Employees have high morale in modern organizations whereas, the morale of the employees working for a classic or traditional organization is not up to the mark due to less flexibility 
and having no part in the decision-making process (Abdulla et al., 2020; Demir et al., 2021; Zaim et al., 2020).

Risk Management: In a modern organization, workers are risk-takers. They can make a reasonable decision without involving the upper management within the defined limits. On the other hand, the employees of the traditional organizations become risk-averse due to certain restrictive policies (Budur, 2018a).

Diversification: Modern organizations are risk-takers, and they venture into the new fields when the opportunity arises. In classical ones it is quite the opposite as they are more conservativism and avoid doing so (Demir et al., 2020; Torlak et al., 2020).

Technology: New organizations are much advanced in using and incorporating technology in the business, whereas the classical organizations tend to resist the change and stick to the old-fashioned way of doing business (Konakli et al., 2017).

\section{Conclusion}

In conclusion management was way straight-forward until Taylor came up with his scientific management principles. He is one of the most important researchers in the field management. Therefore, the aim of this project was to show a bigger picture of scientific management and to compare how organizations transformed after Frederick Taylor introduced his four principles of management. His engineering background played a major role in bringing the paradigm shift and the organizations moved from "the rule of thumb" to "scientific management methods".

Management is important in every walk of life. It is very important to study the history of management, so the managers could avoid making the same mistakes as their older counterpart made. Lastly, there are still thousands of organizations in the world, including hundreds in Kurdistan Region of Iraq, following the older management philosophies. A remarkable difference will be noted in the styles of management if the older and modern management practices are compared in any part of the world. Therefore, it is suggested that in future, the styles of management should be studied and compared in the Kurdistan Region of Iraq.

\section{References}

Abdulla, N., Wrya, H., \& Durmaz, O. (2020). Green Product Perception in Kurdistan Region of Iraq. Black Sea Journal of Management and Marketing, 1(1), 1-15.

Boddewyn, J. (1961). Frederick Winslow Taylor revisited. Academy of Management Journal, 4(2), 100-107.

Budur, T. (2018a). Analytic hierarchy process to evaluate corporate image, trust, and switching cost of GSM operators: A case of Kurdistan Region of Iraq. International Journal of Social Sciences \& Educational Studies, 5(2), 241-250

Budur, T. (2018b). The impact of Al-Ghazali's virtues on organizational commitment and performance: A case Study at private education institutions in Kurdistan Region of Iraq. Icabep, Erbil-Iraq, 2, p21.

Budur, T., \& Demir, A. (2019a). Leadership effects on employee perception about CSR in Kurdistan Region of Iraq. International Journal of Social Sciences \& Educational Studies, 6(1). 142-154. 
Budur, T., \& Demir, A. (2019b). Leadership perceptions based on gender, experience, and education. International Journal of Social Sciences \& Educational Studies, 6(1), 142-154.

Budur, T., \& Poturak, M. (2020). Transformational leadership and its impact on customer satisfaction. Measuring mediating effects of organizational citizenship behaviors. Middle East Journal of Management.

Budur, T., \& Poturak, M. (2021). Employee performance and customer loyalty: Mediation effect of customer satisfaction. Middle East Journal of Management.

Budur, T., Faraj, K. M., \& Karim, L. A. (2019). Benchmarking operations strategies via hybrid model: A case study of caférestaurant sector. Amazonia Investiga, 8, 842-854.

Budur, T., Rashid, C. A., \& Poturak, M. (2018). Students' perceptions on university selection, decision making process: A case study in Kurdistan Region of Iraq. International Journal of Social Sciences \& Educational Studies, 5(1), 133-144.

Decision Making. (n.d.). Retrieved from https://www.oxfordbibliographies.com/view/document/obo-9780199846740/obo9780199846740-0004.xml.

Demir, A., Shawkat, S., Majeed, B.N., \& Budur, T. (2019). Fuzzy AHP and VIKOR to select best location for bank investment: case study in Kurdistan Region of Iraq. In Effective investments on capital markets, Tarczyn'sk W, Nermend K (eds). Springer: Cham; 485-510.

Demir, A. (2020a). Impact of internal marketing on the customer perceptions in SMEs. International Journal of Services and Operations Management.

Demir, A. (2020b). Inter-continental review for diffusion rate and internal-external benefits of ISO 9000 QMS. International Journal of Productivity and Quality Management.

Demir, A., Maroof, L., Khan, N. U. S., \& Ali, B. J. (2020c). The role of E-service quality in shaping online meeting platforms: A case study from higher education sector. Journal of Applied Research in Higher Education. https://doi.org/10.1108/JARHE-08-2020-0253

Demir, A., \& Budur, T. (2019). Roles of leadership styles in corporate social responsibility to non-governmental organizations (NGOs). International Journal of Social Sciences \& Educational Studies, 5(4), 174-183.

Demir, A., Budur, T., \& Heshmati, A. (2020). Antecedents of trust, corporate image, and switching costs: A case in telecommunication services in Kurdistan Region of Iraq. International Journal of Mobile Communications.

Demir, A., Budur, T., Hiwa, M., \& Heshmati, A. (2021). Links between knowledge management and organizational sustainability: Does the ISO 9001 certification have an effect? Knowledge Management Research \& Practice (TKMR), Doi: $10.1080 / 14778238.2020 .1860663$

Drucker, P. F. (2019). The Drucker lectures: Essential lessons on management. Society \& Economy. MGH.

Faeq, M. (2020). Performance Evaluation Criteria Development Process for Academic Staff at Universities. Black Sea Journal of Management and Marketing, 1(1), 59-70.

Ferraro, S. (2016). Frederick Taylor's other Principles. International Journal of Business and Social Science, 7(11), 24-27.

Frederick W. Taylor: Master of Scientific Management. (n.d.). Retrieved from https://www.skymark.com/resources/leaders/taylor.asp.

Kamal, T., \& Shawkat, S. (2020). The impact of dynamic capabilities on knowledge management in Kurdistan Region of Iraq. Black Sea Journal of Management and Marketing, 1(1), 41-48.

Khan, N. U. S., \& Yildiz, Y. (2020). Impact of intangible characteristics of universities on student satisfaction. Amazonia Investiga, 9(26), 105-116.

Kidwell, R. E., \& Scherer, P. M. (2001). Layoffs and their ethical implications under scientific management, quality management and open-book management. Journal of Business Ethics, 29(1-2), 113-124.

Konakli, H., Konakli, Z., Dogan, S., Marjanovic, D., \& Dogan, S. (2017). ACTN3 polymorphism prevalence in general population of six Balkan countries. Genetika, 49(3), 959-968.

Kreitner, R. (1982). The feedforward and feedback control of job performance through organizational behavior management (OBM). Journal of Organizational Behavior Management, 3(3), 3-20. 
Kukrejal, S. (2020, May 15). Overview of Management. Retrieved from https://www.managementstudyhq.com/what-ismanagement.html.

Locke, E. A. (1982). The ideas of Frederick W. Taylor: an evaluation. Academy of Management Review, 7(1), 14-24.

Mee, J. F. (2020, March 17). Frederick W. Taylor. Retrieved from https://www.britannica.com/biography/Frederick-WTaylor.

Megginson, L. C., Mosley, D. C., \& Pietri, P. H. (2001). Supervisory management: The art of empowering and developing people. South-Western College Pub.

Metzgar, C. R. (2004). The principles of scientific management/the one best way: Frederick Winslow Taylor \& the enigma of efficiency. Professional Safety, 49(2), 49.

Mohammed, K. S., Rashid, C. A., Salih, H. A., \& Budur, T. (2020). The role of online teaching tools on the perception of the students during the lockdown of Covid-19. International Journal of Social Sciences \& Educational Studies, 7(3), 178-190.

Mohammed, S. S., Suleyman, C., \& Taylan, B. (2020). Burnout determinants and consequences among university lecturers. Amazonia Investiga, 9(27), 13-24.

Poturak, M., Mekić, E., Hadžiahmetović, N., \& Budur, T. (2020). Effectiveness of transformational leadership among different cultures. International Journal of Social Sciences \& Educational Studies, 7(3), 119-129.

Rahman, M. H. (2012). Henry Fayol and Frederick Winslow Taylor's contribution to management thought: An overview. ABC Journal of Advanced Research, 1(2), 94-103.

Savino, D. M. (2016). Frederick Winslow Taylor and his lasting legacy of functional leadership competence. Journal of Leadership, Accountability and Ethics, 13(1).

Taneja, S., Pryor, M. G., \& Toombs, L. A. (2011). Frederick W. Taylor's scientific management principles: Relevance and validity. Journal of Applied Management and Entrepreneurship, 16(3), 60-78.

Taylor, F. W. (1911). The principles of scientific management. New York.

Taylor's “Scientific Management Principles ... - JOEBM. (n.d.). Retrieved from http://www.joebm.com/papers/342M031.pdf

Top, C., Abdullah, B. M. S., \& Faraj, A. H. M. (2020). Transformational leadership impact on employees' performance. Eurasian Journal of Management \& Social Sciences. 1(1), 49-59.

Torlak, N. G., Demir, A., \& Budur, T. (2019). Impact of operations management strategies on customer satisfaction and behavioral intentions at café-restaurants. International Journal of Productivity and Performance Management.

Torlak, N. G., Kuzey, C., Dinc, MS., \& Budur, T. (2021). Links connecting nurses' planned behavior, burnout, job satisfaction and organizational citizenship behavior. Journal of Workplace Behavioral Health. DOI:10.1080/15555240.2020.1862675

Yolande, BillT, Mind Tools Content Team, Mind Tools Content Team, \& Mind Tools Content Team. (n.d.). Frederick Taylor and Scientific Management: Understanding Taylorism and Early Management Theory. Retrieved from https://www.mindtools.com/pages/article/newTMM_Taylor.htm.

Zaim, H., Demir, A., \& Budur, T. (2020). Ethical leadership, effectiveness, and team performance: An Islamic perspective. Middle East Journal of Management, 8(1), 42-66.

Zardasht, P., Omed, S., \& Taha, S. (2020). Importance of HRM policies on employee job satisfaction. Black Sea Journal of Management and Marketing, 1(1), 49-57. 